\title{
LETTER
}

\section{Surviving sepsis bundle compliance: getting the time of the day it deserves}

\author{
Madhura Borikar*, Ashish Tikotekar and Amay Parikh \\ See related research by Almeida et al., http://ccforum.com/content/17/2/R79
}

We appreciate the efforts of Almeida and colleagues to establish differences in compliance to the Surviving Sepsis Campaign (SSC) bundle for patients with community-acquired severe sepsis, but we have some concerns [1]. The study is similar to other studies noting a difference in delivered care based on time [2].

Parikh and colleagues showed improvement in quality measures with the use of bundles and implementing the Leapfrog Intensive Physician Staffing Standard [3]. Almeida and colleagues showed only a $2 \%$ overall compliance rate with the entire 6-hour bundle, which is too small to draw conclusions. The difference between the compliance rate of the SSC bundle for day versus night was not statistically significant. The authors agree and state that the outcomes in community-acquired severe sepsis improve when all components of the SSC bundle are executed together [4].
However, the authors derive conclusions based on the compliance of individual components.

Time zero was defined as the hospital entrance time. However, community-acquired severe sepsis was defined as the onset of infection before hospital admission or infection becoming evident in the first 48 hours. The patient presenting after 6 hours but before 48 hours would by default fail the compliance of the SSC bundle.

Patient time groups (day and night) were different from nurse shifts (three shifts in a 24-hour period). The study did not take into account the possibility of handoff errors from nursing shift changes. Also the time between some patients' hospital entrance and the completion of bundle components could have overlapped the cutoff time for two patient groups.

\section{Authors' response}

Teresa Cardoso, Mónica Almeida, Orquídea Ribeiro, Altamiro Costa-Pereira and Irene Aragão

We thank Borikar and colleagues for their interest in our work. Unlike previous studies, our study focused on septic patients responsible for the higher proportion of nonscheduled hospital admissions. The study focuses on the need to adapt clinical emergency teams, in particular the nursing staff, to the variations of workload over the 24-hour period, in order to achieve the desired quality of care.

In our study, compliance with the resuscitation bundle was low - but similar rates have been reported in similar studies, including the results of the SSC itself [5] - which is probably derived from the difficulty of achieving early invasive monitoring. This is an almost universal problem and probably one of the reasons that led the 2012 SSC review to split the first bundle into two periods: the first 3 hours

\footnotetext{
* Correspondence: madhuborikar@gmail.com

Pulmonary and Critical Care Division, Department of Medicine, Robert Wood Johnson Medical School, 1 Robert Wood Johnson Place, PO Box 19, New Brunswick, NJ 08903-0019, USA
}

and 6 hours [6]. During the first 3 hours, doctors should accomplish serum lactate measurement, cultures for microbiology, broad-spectrum antibiotic administration and fluid administration. The invasive monitoring was postponed to the second period, probably because of the need to obtain support for this. We have already pointed this out in a previous paper [7]: accomplishing these simple actions available to any doctor in any hospital setting early on leads to higher compliance and a greater impact on mortality. When these essential measures are applied, the next step is referral to a differentiated unit for invasive monitoring and care from expert clinicians in appropriate settings such as intermediate or intensive care.

\section{Abbreviations \\ SSC: Surviving Sepsis Campaign.}

Competing interests

The authors declare that they have no competing interests. 


\section{Acknowledgements}

The research by $\mathrm{TC}$ and colleagues was supported by an unrestricted grant from ASSUCIP (Associação de Apoio à Unidade deCuidados Intensivos Polivalente, Hospital de Santo António, Porto, Portugal).

Published: 04 Sep 2013

\section{References}

1. Almeida M, Ribeiro O, Aragao I, Costa-Pereira A, Cardoso T: Differences in compliance with Surviving Sepsis Campaign recommendations according to hospital entrance time: day versus night. Crit Care 2013 17:R79

2. Kostis WJ, Demissie K, Marcella SW, Shao YH, Wilson AC, Moreyra AE: Weekend versus weekday admission and mortality from myocardial infarction. N Engl J Med 2007, 356:1099-1109.

3. Parikh A, Huang SA, Murthy P, Dombrovskiy V, Nolledo M, Lefton R, Scardella AT: Quality improvement and cost savings after implementation of the Leapfrog intensive care unit physician staffing standard at a community teaching hospital. Crit Care Med 2012, 40:2754-2759

4. Levy MM, Dellinger RP, Townsend SR, Linde-Zwirble WT, Marshall JC, Bion J, Schorr C, Artigas A, Ramsay G, Beale R, Parker MM, Gerlach H, Reinhart K, Silva E, Harvey M, Regan S, Angus DC: The Surviving Sepsis Campaign: results of an international guideline-based performance improvement program targeting severe sepsis. Intensive Care Med 2010, 36:222-231.
5. Surviving Sepsis Campaign, Levy MM, Dellinger RP, Townsend SR, Linde-Zwirble WT, Marshall JC, Bion J, Schorr C, Artigas A, Ramsay G, Beale R, Parker MM, Gerlach H, Reinhart K, Silva E, Harvey M, Regan S, Angus DC: The Surviving Sepsis Campaign: results of an international guideline-based performance improvement program targeting severe sepsis. Crit Care Med 2010, 38:367-374.

6. Surviving Sepsis Campaign Guidelines Committee including the Pediatric Subgroup, Dellinger RP, Levy MM, Rhodes A, Annane D, Gerlach H, Opal SM, Sevransky JE, Sprung CL, Douglas IS, Jaeschke R, Osborn TM, Nunnally ME, Townsend SR, Reinhart K, Kleinpell RM, Angus DC, Deutschman CS, Machado FR, Rubenfeld GD, Webb SA, Beale RJ, Vincent JL, Moreno R: Surviving sepsis campaign: international guidelines for management of severe sepsis and septic shock: 2012. Crit Care Med 2013, 41:580-637.

7. Cardoso T, Carneiro AH, Ribeiro O, Teixeira-Pinto A, Costa-Pereira A: Reducing mortality in severe sepsis with the implementation of a core 6-hour bundle: results from the Portuguese community-acquired sepsis study (SACiUCl study). Crit Care 2010, 14:R83.

\subsection{6/1364-8535-17-447}

Cite this article as: Borikar et al:: Surviving sepsis bundle compliance: getting the time of the day it deserves. Critical Care 2013, 17:447 